\title{
The Automobile Insurance Industry and Federal Takeover
}

\author{
Jeffèy O'Connell $\uparrow$
}

It is part of the badge of being a red-blooded American businessman to oppose government regulation of business and-as the ultimate anathema-to oppose government takeover, i.e., government operation of an enterprise that might otherwise be run by private business.

Although the insurance industry has long been regulated on the state level, there seems little or no fear of takeover by state government. But nowhere does one find fear of takeover by the federal government any stronger than in the insurance industry. Nor is this fear totally groundless. Insurance-tied inextricably to misfortune and the welfare of those who suffer from it-is obviously fraught with public interest. That interest is the reason for the intense regulation (in theory at least) of insurance in the first place. Clearly government is concerned with what succor is available to victims of accidents and catastrophe and their survivors. Clearly, too, government provides aid to unfortunates from public coffers, often thereby competing, more or less, with private insurance. Social security, payable to survivors of decedents, to the permanently disabled, to the retired, and to the aged for medical care, is the classic example of such government aid. And in the case of social security, the aid is somewhat analogous to insurance since the recipient contributes to the system, thus, in a measure, paying "premiums" for the payout he eventually receives. This makes the competition with private insurance all the more obvious.

The scope of social security has expanded through the years with coverage for new categories and provision for higher payments. Many an insurance executive anxiously looks over his shoulder to see to what extent government insurance is catching up with him. In fact, however, the growth of social security and other forms of social insurance has been very modest in the United States compared to other industrialized countries. Nevertheless, the insurance executive still feels the threat of government takeover looming large.

To examine the depths of this fear-and how realistic it is-we might

$\dagger$ Professor of Law, The University of Illinois. 
turn to the current controversy over reform of automobile insurance. It is true that there have recently been several proposals for turning over at least a part of automobile insurance to federal insurance, i.e., insurance written and administered by the federal government. ${ }^{1}$ In at least one instance, the seriousness of these proposals has been exaggerated. It is often pointed out that Daniel P. Moynihan, former Director of the Joint Center for Urban Studies at Harvard-M.I.T. and currently Executive Secretary of President Nixon's Council for Urban Affairs, has advocated a system of federal insurance for traffic accidents. ${ }^{2}$ In fact, a close reading of Moynihan's article reveals that his proposal for federal insurance was actually a less favored alternative to a system of private automobile insurance, payable, unlike the present tort system, without regard to who is at fault in the accident. Speaking of such nonfault insurance to be administered by private insurance companies whereby an insurance company will pay its own insured regardless of fault, Moynihan stated:

This is exactly what happens, for example, with fire insurance. Householders buy their own insurance. If their house catches fire, regardless of who is responsible (barring fraud), their company compensates them. The settlement process involves a relationship between a business firm and one of its clients. Thus, the many hundreds of thousands of fire insurance claims are settled each year with nothing like the turmoil accompanying automobile claims.

It is hard to fault the Basic Protection scheme ${ }^{3}$ [for auto-

I See, e.g., W. Blum \& H. Kalven, Public Law Perspectives on a Private Law Problem-Auto Compensation Plans (1965); Conard \& Jacobs, New Hope for Consensus in the Automobile Injury Impasse, 52 A.B.A.J. 533, 534 (1966); Conard, The Economic Treatment of Automobile Injuries, 63 Mich. L. REv. 279 (1964).

2 Moynihan, Next: $A$ New Auto Insurance Policy, N.Y. Times, Aug. 27, 1967, § 6 (Magazine), at 26, 80-82.

3 The Basic Protection Automobile Insurance Plan is set forth most fully, along with documentation for its pressing need and a draft statute, in R. KEETON \& J. O'CONNELL, Basic Protection for the Traffic Victim: A Blueprint for Reforming Automobile Insurance (1965) [hereinafter cited as BAsic Protectron]. For a slightly revised and updated version of chapter 6 of this book, see Keeton \& O'Connell, Basic Protection Automobile Insurance, 1967 U. ILL. L.F. 400, 408-39, in CRISIS IN CAR INSURANCE 40, 48-79 (R. Keeton, J. O'Connell \& J. McCord, eds. 1968) [hereinafter cited as CRIsis]. See also R. Keeton \& J. O'Connell, After Gars Crash-The NeEd for Legal and Insurance REFORM (1967) (a version written for the general reader).

The Basic Protection Plan has two main features: (1) a new form of compulsory automobile insurance (called Basic Protection Coverage) will compensate all those injured in traffic accidents without reference to anyone's fault or lack of it. Basic Protection Insurance will pay up to limits of $\$ 10,000$ per victim for any victim's out-of-pocket losses-consisting principally of medical expenses and wage losses. Payment would not be made under Basic Protection for pain and suffering. Whenever a motorist carrying Basic Protection Plan insurance is involved in an accident, his own Basic Protection 
mobile insurance payable by one's own insurance company regardless of fault]. The authors [of the Basic Protection Plan] are right . . . in the all-important perception as to what it is Americans are good at. We are good at maintaining business relationships once a basis for mutual self-interest is established. The Basic Protection Plan would establish one. ${ }^{4}$

The trouble is that many insurance executives view such a proposal of nonfault insurance whereby a company pays its own insured regardless of who is to blame for the accident as inevitably leading to federal insurance. Proposals for nonfault auto insurance have been made since the early 1930 's ${ }^{5}$ and until very recently the almost unanimous response of the insurance industry was to dismiss such plans, often labeling them as "socialistic."6

At first blush it is a little hard to understand why such plans should be labeled as socialistic. The term "socialism," after all, connotes governmental ownership of the means of production and control of the distribution of goods. ${ }^{7}$ But almost all the plans proposed for nonfault automobile insurance have explicitly preserved private insurance as the means of administering the system. ${ }^{8}$ Even if the definition of "socialism" be stretched to include increased governmental regulation of business, the reform proposals usually do not change the basic pattern of insurance regulation from that operating today.

In one sense, however, it may be understandable that nonfault in-

Insurance Company will compensate him; (2) the second feature of the plan is a law that partially exempts from liability for negligent driving all those insured under Basic Protection (which will include virtually all motorists, since Basic Protection Insurance will be a prerequisite to registration of an automobile). In those tort cases in which damages for pain and suffering do not exceed $\$ 5,000$, and other damages, such as those for medical expenses and wage loss, do not exceed $\$ 10,000$, liability for negligence would be eliminated. In all other cases, the exemption would reduce the liability for negligence by the same amount.

4 Moynihan, supra note 1 , at 82.

5 See Commttee to Study COMPEnsation for Automobite Accidents, Report to the Columbia UNIversity Council for Research in THE SOcial Sciences (1932). For other proposals for nonfault automobile insurance see A. EHRENZwEIG, "FulL Am" INSurance for the Traffic Victim-A Voluntary Compensation PLan (1954), reprinted under the same title in a slightly revised form in 43 CALIF. L. REv. 1 (1955); L. GREEN, Traffic Victims-Tort Law and Insurance (1958); Morris \& Paul, The Financial Impact of Automobile Accidents, 110 U. PA. L. REv. 913 (1962). For a discussion of these and other proposals of reform, see Basic Protecrion 124-89.

o See, e.g., remarks of W.J. Jeffery, Chairman and President of the United States Fidelity and Guarantee Company, The National Underwriter (Fire \& Casualty), Oct. 13, 1967, at 2, col. 1; see also The Workshop Sessions: Summary Report, 1967 U. ILL. L.F. 618, 630-1, in Crisis 258, 270-1.

7 Webster's ThIRd New International Dictionary of the English Language 2162 (unabr. 1961).

8 See Basic Protection, app. B, Item No. 10, at 532-3. 
surance should be labeled "socialistic." The development of liability based on fault coincided with the industrial revolution. Nor was this joint development by chance, according to Fowler Harper and Fleming James. "It was but another manifestation of the individualism which underlies laissez faire as a political philosophy." Industrial activity was not to be burdened with the inevitable toll it exacts in human life and limb unless the activity had not been carried out with due care. Also, there was to be no imposition of liability unless the defendant had been "guilty of some personal moral shortcoming,"10 and there was to be no leveling by lumping the careful and careless together. Given the earlier identity of the fault concept with the heyday of laissez faire capitalism, perhaps it is not surprising that the converse identification of the opposite of payment based on fault-namely payment based on other than fault-should be identified with the opposite of laissez faire capitalism - namely socialism. But, in fact, the equation of payment without reference to fault with socialism is specious. Insurance payable without reference to who is at fault is perfectly consistent with private enterprise as generations of private insurance coverage of workmen's compensation have demonstrated.

But if the historical argument falls, insurers have another reason they advance for identifying payment of insurance without reference to fault with government insurance. According to James Kemper, Jr., President of the Kemper Insurance Companies,

the surest road to federal regulation and federal automobile insurance is the Basic Protection plan.

-...

... [T] he Basic Protection plan, a compulsory accident insurance system which . . . largely eliminates the need for determining fault, is primarily a system for dispensing benefits, and therefore a natural precursor to a complete takeover of this segment of the private sector by the federal government.

... [I] $t$ is a matter of cause and effect: Basic Protection leading irresistably to federal insurance. ${ }^{11}$

But why should making insurance compulsory and payable without reference to fault lead "irresistably" to federal insurance? It certainly has not done so in the case of workmen's compensation. Certainly the wide variety of other forms of nonfault insurance-such as accident and health coverage and fire insurance-have not led "irresistably" to

O 2 F. Harper \& F. James, The Law of Torts § 12.3, at 752 (1956).

$10 \mathrm{Id}$.

11 Kemper, The Basic Protection Plan: Reform or Regression?, 1967 U. ILL. L.F. 459, 469, in CRISIS 99, 109. 
their being taken over by the federal government. In other words, the mere fact that a system of insurance is "primarily a system for dispensing benefits" does not make such a system "a natural precursor to a complete takeover of [that] . . . segment of the private sector by the federal government."12

Nevertheless, some insurance executives continue to equate simplifying auto insurance with a federal takeover. One version of the argument-as I have pieced it together in conversation with different insurance personnel-seems to run something like this: The simple1 and easier the manner of payment, the more readily the government can step in and take it over, absorbing the coverage in its ever-expanding social security program. On the other hand, the more the criterion for payment is complicated, the more argument there is likely to be over what, if anything, is to be paid, which in turn undermines the government's confidence in its ability to administer the program. In other words, the government has little taste for insurance which is going to lead to constant battles over who and what is to be paid. Thus, the more the flavor of the complicated tort system can be preserved, the less likely government takeover of that form of insurance.

Does this explain, at least in part, the formula of the Guaranteed Benefits Plan, principally sponsored by the American Mutual Insurance Alliance, wherein the victim of an auto accident is given a rather complicated option, in dealing with the other driver's insurance company, of taking nonfault benefits for his out-of-pocket loss and waiving his tort claim or, on the other hand, pursuing his tort claim? ${ }^{13}$

12 Id. Mr. Kemper also argues that confusion about how to set rates for new nonfault auto insurance without the benefit of prior loss experience will so overburden state regulators that it "will increase the pressure for federal regulation of the insurance industry." Id. In turn, the federal government will be as unable to rate this new insurance as state governments and at this point federal insurance will be "irresistable," among other things, to clear up the interstate chaos caused by differing versions of nonfault insurance having been passed in some states along with a tort system being retained in others. Id.

But in answer to this, are we really so locked into the present system that if we want to preserve private enterprise for the insurance industry, along with state regulation, we cannot institute significant reform, so appalling are the problems of rating new forms of insurance? Were the problems of rating workmen's compensation when it was new that bad? Obviously not. As to the supposed impossibility of having various systems for paying insurance claims in different states, were the problems of having differing versions of the Uniform Commercial Code, as well as the old commercial law, in effect in different states so overwhelming that we were driven to a federal commercial law? Obviously not. Even more fundamentally, is Mr. Kemper's belief in the federal system so unsubstantial that he thinks states cannot experiment with fundamental legal reform without "irresistably" calling forth federal intervention? If that is so, one of the great virtues of the federal system-the capacity of individual states to act as laboratories experimenting with reform-has disappeared.

13 For discussion of the Guaranteed Benefits Plan, see King, The Insurance Industry and Compensation Plans, 43 N.Y.U.L. REv. 1137, 1152-7 (1968). 
When I gently chided one insurance executive that the Guaranteed Benefits Plan seemed purposely to build in friction and a complicated mode of payment in order to stave off government insurance, he replied, no doubt sincerely, that the Guaranteed Benefits Plan retains the fault criterion, not so much as a complication for complication's sake, but because of the belief that the public wants to retain the fault criterion-or at least have the option of doing so after an accident. Such a reason, assuming it is valid, would make sense. However, several recent surveys would seem to indicate that the public would prefer being guaranteed payment by one's own insurance company for outof-pocket loss regardless of fault as opposed to taking the chance of recovering more if, and only if, a tort claim can be established. A survey conducted at the University of Illinois showed 71 per cent of those responding preferring such nonfault payment. ${ }^{14} A$ survey conducted by the American Insurance Association showed about 72 per cent of those expressing an opinion favoring nonfault insurance. ${ }^{15}$ And a poll conducted by the Minneapolis Tribune reversed a finding of an earlier poll by the same paper which indicated that the public prefers the fault system. Although the earlier poll showed some 64 per cent of those expressing an opinion opposed to nonfault insurance, ${ }^{16}$ the later poll, which asked the respondents to assume there would be prompter payment and lower insurance premiums under nonfault insurance by almost 25 per cent, found 67 per cent of those expressing an opinion favoring such nonfault insurance. ${ }^{17}$

But the important point is that whereas public preference is a legitimate factor in deciding how automobile insurance ought to be restructured, if at all, speculation on which mode of insurance is more or less likely to lead to government takeover seems both far-fetched and not a very sound basis for structuring automobile insurance reform.

14 The results of the survey are contained in a book by J. O'ConNELI. \& W. Wirson, Car Insurance and Consumer Desires on the Fall, 1969 list of the University of Illinois Press.

15 Awareness of and Attitude Toward a New Kind of Automobile Insurance, ORC Caravan Surveys, Inc. (1968). For a report of the survey, see The National Underwriter (Fire \& Casualty), Feb. 14, 1969, at 1, col. 2. It should be noted that the survey conducted on behalf of the American Insurance Association assumed, unlike the University of Illinois survey, that "on the average, rates [for the nonfault insurance] would be lower by $30 \%$." The survey found $56 \%$ favoring the new nonfault insurance, $21 \%$ preferring the present system, $21 \%$ undecided, $1 \%$ preferring something else, and $1 \%$ going unreported. These figures mean that $72 \%$ of those expressing an opinion favored nonfault insurance.

16 Minneapolis Tribune, Sept. 8, 1968. This poll showed $60 \%$ opposed to nonfault insurance, $34 \%$ in favor of it, and $6 \%$ undecided. These figures mean that $64 \%$ of those expressing an opinion were opposed to nonfault insurance.

17 Minneapolis Tribune, April 6, 1969. This poll showed $62 \%$ favoring nonfault insurance, $31 \%$ opposed, and $7 \%$ with no opinion. These figures mean that $67 \%$ of those expressing an opinion favored nonfault insurance. 
In the first place, there has been simplified nonfault criterion for payment of claims in many forms of insurance for generations without governmental takeover. Secondly, the reason for government takeover of any line of insurance seems to be not so much the ease of payment, but whether private insurance is performing adequately in selling and servicing the market. For example, Medicare (medical insurance for the aged under social security) came into being because private insurance companies were not providing adequate medical insurance for the aged. Similarly, federal crop insurance and flood insurance came about because of the inadequacy of privately offered insurance. As an additional example, federal reinsurance to cover property in the inner city was an outgrowth of the inadequacy of the private market and indeed occurred at the invitation of the insurance industry.

Concerning both federal regulation and federal ownership of automobile insurance, Robert Rennie, Vice-President of Nationwide Insurance Company, stated in response to James Kemper's fears:

I must also take issue with Mr. Kemper's comments on the threat of federal regulation and federal preemption. In my view, the threat lies not in reform of state systems, but in the absence of state action. It is when the states fail to follow clearly identified lines for dealing with a social problem that the federal government moves in. ${ }^{18}$

As I read Mr. Rennie, he is convinced that federal automobile insurance will not follow from simplifying the insured event but rather from too strong a commitment to the status quo and all its inadequacies.

That not all the insurance industry equates simplifying the insured event with an "irresistable" takeover by the federal government is shown by the recent so-called Complete Protection Plan proposed by the American Insurance Association, a trade organization of 168 stock insurance companies who write approximately 38 per cent of all automobile insurance in the United States. Under this plan, in every instance and without any option, one's own insurance company would pay a victim for his out-of-pocket expenses, regardless of fault, and the tort suit arising from auto accidents would be completely eliminated.19 Regardless of the ultimate merits of this proposal (about which, as with the Basic Protection Plan, there is legitimate difference of opin-

18 Rennie, Remarks, 1967 U. ILL. L.F. 474, 477 (1967), in CrISIS 114, 117.

19 American Insurance Association, Report of the Special Commitiee to Study and Evaluate the Keeton-O'Connell basic Protection Plan and Automobile Accident REPARATIONs (1968). For a discussion of the plan, see King, supra note 13, at 1161-4. 
ion), it does serve to illustrate that at least some segments of the insurance industry can think about streamlining the insured event and replacing tort insurance with nonfault insurance without thinking about such a change as "socialism" and without being convinced that federal writing of insurance will necessarily follow. 